\title{
Food habits and trophic level of Anabas testudineus in floodplain lake, Lake Semayang, East Kalimantan
}

\author{
Mohammad Mustakim ${ }^{1,2,{ }^{*}, \text { Sutrisno Anggoro }}{ }^{1}$, Frida Purwanti $^{1}$, Haeruddin $^{1}$ \\ ${ }^{1}$ Doctoral Program in Coastal Resources Management, Faculty of Fisheries and Marine Science, \\ Diponegoro University. Tembalang, Semarang 50275, Central Java, Indonesia. \\ ${ }^{2}$ Department Aquatic Resources Management Faculty of Fisheries and Marine Science Mulawarman \\ University Jl. Gunung Tabur Kampus Gunung Kelua East Kalimantan, Indonesia.
}

\begin{abstract}
This research studied the food habits and trophic level of $A$. testudineus in a floodplain lake, Lake Semayang, East Kalimantan. The lake has characteristics of both swamp and lake habitats. The research was conducted from February 2017 until January 2018. During the study, 558 samples of Anabas testudineus were analyzed. The Index of Stomach Content (ISC) in the swamp habitats ranged from $4.32-39.59 \%$, with an average of $19.35 \%$, while in the lake habitat ranged from $3.68-38.46 \%$ with an average of $16.03 \%$. Index of Preponderance (IP) value showed the dominant food item in the fish stomach is animal (62.58 - 79.66\%), plants $(25.18-42 \%)$, and undetectable food $(\geq 5 \%)$. Based on the type and composition of the food, A. testudineus can be classified as omnivorous more inclined to carnivorous. The trophic level of this species changes along with increasing size length.
\end{abstract}

\section{Introduction}

Lake Semayang $(9.132 \mathrm{Ha})$ is one of the most extensive wetlands in the Central Mahakam Region of East Kalimantan Province [1]. Lake Semayang is a floodplain lake with habitat characteristics of both swamps and lakes [2]. The lake habitat has features such as a large water surface, a relatively large number of aquatic plants in the littoral area, and the depth of water tends to be deeper than swamp habitat $[3,4]$. The swamp habitat is characterized by the presence of dense aquatic plants and shallow water depths [5,6,7].

Lake Semayang has been known as a habitat of some fish species, [8] reported 46 fish species lived in this lake, including A. testudineus [2, 9]. A. testudineus is one of the affordable sources of animal protein in some Asian countries such as Bangladesh and Malaysia [10, 11]. This fish has high economic value and favored in East Kalimantan because it has good taste [12]. This situation has been implicated in the high market demand for $A$. testudineus, in which the supply is highly dependent on fishing activity. This situation may

\footnotetext{
* Corresponding author: moh.mustakim@fpik.unmul.ac.id; mustakim.unmul2005@gmail.com
} 
threaten the population of $A$. testudineus. Therefore it is necessary to manage the $A$. testudineus resources optimally and sustainably.

Previous research on A. testudineus in the Central Mahakam area has been carried out, which studied the aspects of reproduction [13], population dynamics [9], and growth patterns of A. testudineus [2], but studies related to food habits and trophic level is still scarce. The feeding habits of fish is one of the most critical information in managing fish resources because it considered as essential information for domestication and cultivation efforts. In each stage of growth requires a relatively different energy source (food source). [14] reported when the fish spawn, the fish will change its feeding composition and then it will return to normal after breeding. Changes in food habits are obtained by conducting analysis on the most significant preponderance on fish species at each interval size and each stage of Gonad development. In addition to food habits, the estimation of the fractional trophic level of the fish species in the habitat needs to be known. The fractional trophic level serves as a reference to assess the impact of changes that occurs on the fish community food webs, and also as an important material for ecosystem-based fish resource management [15]. Trophic level interactions can describe the position of an organism in the food webs and its interplay between the upper trophic level (predatory) and prey and opposite [16].

Based on the previous description, and by taking into account the decreasing population of A. testudineus in Lake Semayang, the research on its food habits and trophic level is needed as basis information for resource management. Comprehensive information is needed so that A. testudineus resources can be optimally utilized and sustainably managed.

\section{Material and Methods}

\subsection{Time and Location of Research.}

The research was conducted in Lake Semayang. The sampling stations are fishing locations that were commonly visited by local fishermen. The sampling stations included swamp habitat (stations I, IV and V) and lake habitat (stations II, III and V) (Figure 1).

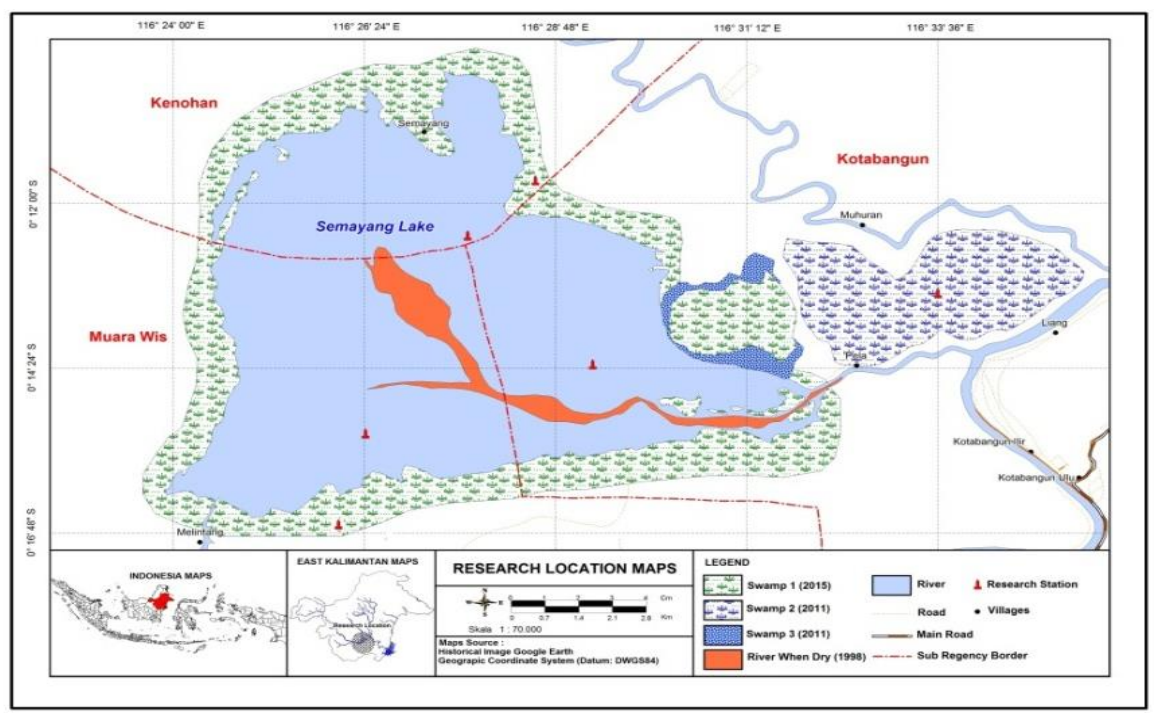

Fig. 1. Research Location 


\subsection{Data collection.}

The A. testudineus sample collection was carried out monthly from February 2017 until January 2018 by using fishing traps that commonly used in Semayang lakes. After collection, fish specimens were transferred to the icebox. The morphometric analysis was performed in the laboratory. Total length (TL) in $\mathrm{cm}$ was measured for each of individual specimen from tip of mouth to the tip of upper lobe of caudal fin using a measuring scale to the nearest 0.1 $\mathrm{mm}$ and Total body weight (TBW) in grams was measured for each specimen to the nearest of 0.001 gr using an electronic balance. After that, each specimen was dissected and the intestine was removed gently. The structure of the digestive tract was performed by macroanatomy observation of the position of the mouth, tooth shape, gill, pharyngeal. The total weight of intestine (TWI) and Total length of intestine (TLI) was measured to the nearest of $0.01 \mathrm{gr}$ and $0.1 \mathrm{~mm}$. Concerning the measurement of the Index of Stomach Content (ISC): the whole stomach was detached from the digestive system by removing the posterior part of the esophagus and intestine. The stomach weight including its content weight was measured. The stomach was dissected and their contents were poured into a Petri dish. Intestine content analysis was performed to identify the food items available in the intestine to determine the food habit along with the determination of the most preferable food class for the fish species following the index of preponderance.

\subsection{Data analysis.}

\subsubsection{Structure of the digestive tract}

The relative length of the intestine (RLI) is the most common index which used to determine the feeding habit of fishes [17]:

$$
\begin{aligned}
& \text { The relative length of intestine ratio }(\%)=\frac{I L}{B L} \times 100 \\
& \mathrm{IL} \quad: \text { Intestine Length (mm) } \\
& \mathrm{BL} \quad \text { : Body Length (mm) }
\end{aligned}
$$

Calculation of ISC (Index of Stomach Content) was carried out to determine fish feeding activities, namely by calculating the ratio between the weight of gastric contents and the total weight of the digestive tract of fish at each observation time. The ISC was calculated using the following formula $[18,19]$.

$$
\mathrm{ISC}=(\mathrm{SCW} / \mathrm{DW}) \times 100
$$

ISC : Index of Stomach Content $(\%)$

SCW : Stomach Content weight (gram)

DW : Digestive organ Weight (gram)

\subsubsection{Food Habits}

The composition analysis of gastric contents was carried out using the index of the largest part (Index of Preponderance) by [20]:

$$
\mathrm{IP}=\frac{V i O i}{\sum_{i=I}^{n} V i O i} \times 100
$$




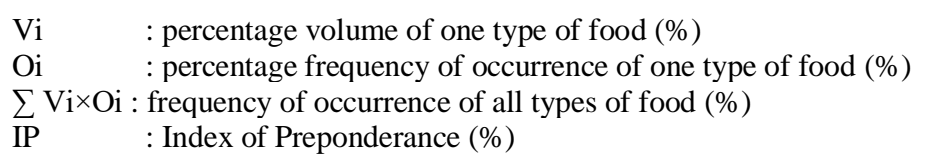

Based on the Index of Preponderance value obtained from the results of the study, the order of fish food habits is divided into three categories; IP $>25 \%$ : main food, $5 \% \leq \mathrm{IP} \geq$ 25\%: complementary food, IP <5\%: additional food [21].

\subsubsection{Trophic Level}

The trophic level of A. testudineus was determined to identify whether the species is classified as herbivore, omnivore, or carnivore. The trophic level was calculated using the following formula [22]:

$$
\mathrm{Tp}=1+\sum(\operatorname{Ttp} \times \mathrm{Ii} / 100)
$$

$\begin{array}{ll}\text { Tp } & : \text { Trophic Level } \\ \text { Ttp } & : \text { The trophic level feed composition group of the to-p } \\ \text { Ii } & : \text { Index of Preponderance feed composition group to-i }\end{array}$

Trophic level category of fish is classified as: Trophic Level $2=$ Herbivore fish; Trophic Level 2.5=Omnivore fish; Trophic Level 3= Carnivorous Fish

\section{Results and Discussion}

\subsection{Structure of the digestive tract}

Macro-anatomic structure of the digestive organs of A. testudineus is described in Figure 2. The position of the mouth is in the front end; this position is called the terminal type [23, 24], the fish have teeth and tongue. The sharp teeth come up from lower teeth longer than The upper teeth. The pharynx is located between the right and left gills; the pharynx has teeth that are useful for grinding the incoming food. The gills of the fish are short and large.

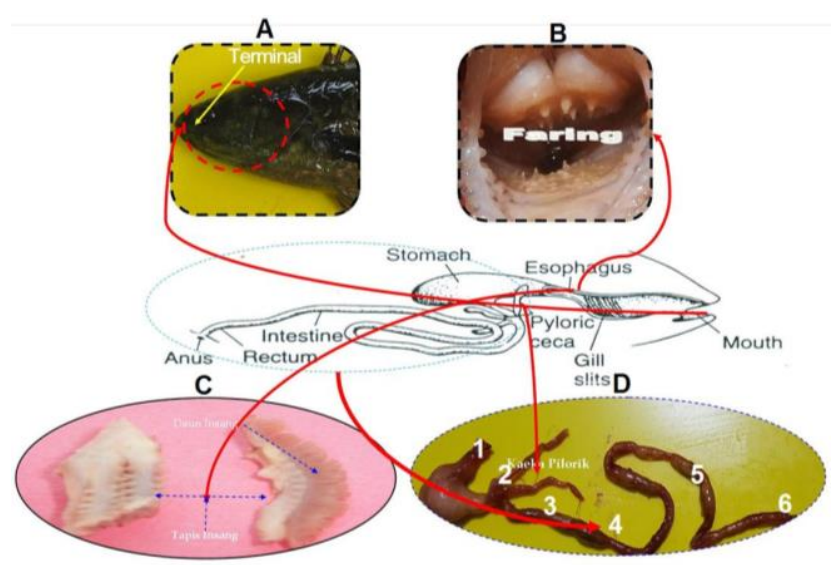

Fig. 2. The anatomical structure of gills and digestion of A. testudineus A: mouth position; B: pharyngeal form; C: gill shape, gill tapis, gill leaves; D: digestive tract, 1. esophagus, 2 pyloric caeca, 3. Anterior intestine, 4. middle intestine, 5. Posterior intestine, 6. anal. 
The esophagus of the fish is a short, intermediate channel of the pharynx and associated with the stomach. A. testudineus has a simple stomach structure; the stomach has two Pyloric caeca, it was usually beneficial in the process of digestion and absorption of food. The intestine of the fish is divided into three parts (the anterior, middle, and posterior). The intestinal structure of the A. testudineus has one fold.

The RLI ratio of $A$. testudineus males in the lake habitat is $0.86 \pm 0.013$, the RLI ratio for females is $0.91 \pm 0.0089$. On the other habitat (swamp area) RLI is $0.93 \pm 0.014$ for females (table 1). These results indicated that A. testudineus is categorized as carnivorous fish. According to [25], the intestinal length of carnivorous fish is generally shorter than the total body length. This is related to the digestive process which is relatively faster because the food is in the form of meat. Furthermore, the intestine has three parts with one fold, the intestinal structure that has one fold and has two pyloric caeca, same as salmonids and gadoids [26], this form is usually owned by omnivores.

According to [27], the herbivorous fish digestive tract is several times its body length and can reach five times its body length, while the intestinal length of carnivorous fish is shorter than its total body length, and the intestinal length of omnivorous fish is only slightly longer than its total body. The tooth shape of the fish is spiky and sharp; this is the tooth shape of a predatory fish, the gills of the fish are not functioning as a feeding filter because they are sparse and short, while the pharynx of the fish has teeth that erode food. According to [14], fish with pharyngeal forms that have teeth are usually categorized as omnivores, euryphagous, and opportunistic eaters in various ecological areas.

Table 1. Biometric Measurement A. testudineus

\begin{tabular}{lcccc}
\hline \multirow{2}{*}{\multicolumn{1}{c}{ Parameters }} & \multicolumn{2}{c}{ Swamp Habitats } & \multicolumn{2}{c}{ Lake Habitat } \\
\cline { 2 - 5 } & $\begin{array}{c}\text { Male } \\
(\text { Avg } \pm \text { SD })\end{array}$ & $\begin{array}{c}\text { Female } \\
(\text { Avg } \pm S D)\end{array}$ & $\begin{array}{c}\text { Male } \\
(\text { Avg } \pm S D)\end{array}$ & $\begin{array}{c}\text { Female } \\
(\text { Avg } \pm S D)\end{array}$ \\
\hline Number ( $)$ ) & 168 & 164 & 121 & 105 \\
Total Length (mm) & $123 \pm 13.36$ & $129.86 \pm 14.58$ & $122.11 \pm 12.96$ & $129.47 \pm 16$ \\
Intestine Length (mm) & $110 \pm 12.76$ & $118.45 \pm 14.34$ & $111.97 \pm 12.78$ & $120.27 \pm 15.85$ \\
Intenstine Length Relative (\%) & $0.86 \pm 0.013$ & $0.91 \pm 0.0089$ & $0.92 \pm 0.089$ & $0.93 \pm 0.014$ \\
\hline Source: Primary Data, 2017-2018 & & & &
\end{tabular}

The ISC value in lake habitat ranged from $3.68-38.46 \%$ with an average of $16.03 \%$, while In the swamp habitat, the ISC was ranged from $4.32-39.59 \%$ with an average of $19.35 \%$. These values indicated that the stomach capacity of A. testudineus is relatively low. This condition might be related to sampling time carried out in the morning until late afternoon. A. testudineus is known as a type of fish that exhibits negative phototaxis, where the dominance of feeding activities at night. A previous study [28] reported that $A$. testudineus is found to have more active feeding at night. The relatively low ISC values found in this study could reflect that the stomach content of the fish was already digested prior to catch.

\subsection{Index of Preponderance}

Stomach material content of A. testudineus was identified and we found that $40-95 \%$ of the stomach content was animal parts (fish, shrimp, insects, snails, and worms), 15-48\% was plants, and $0.38-5 \%$ was undetectable food (Figure 3 ) 

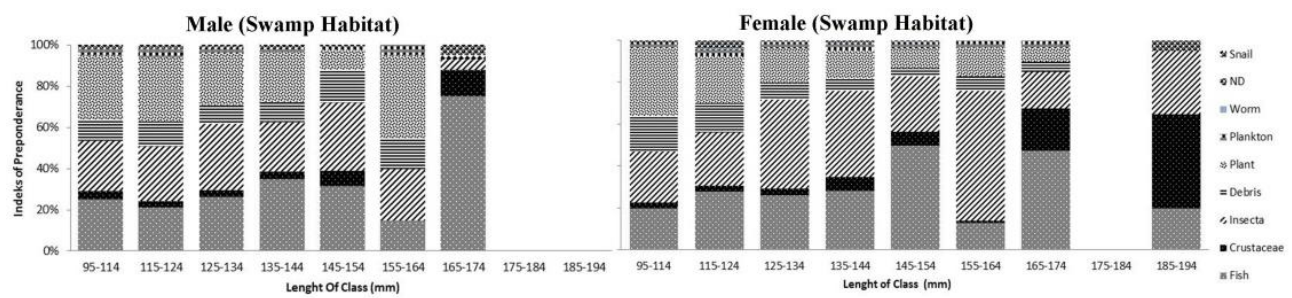

Fig. 3. Index of Preponderance based on the length size range in Swamp Habitat
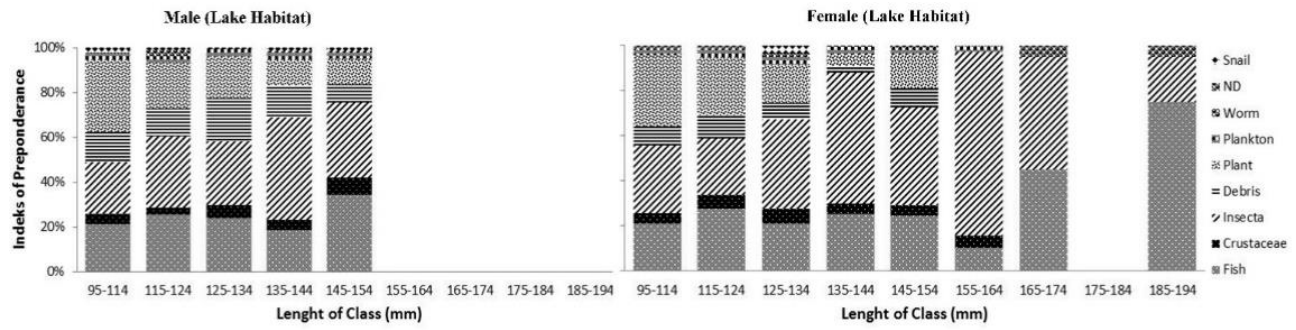

Fig. 4. Index of Preponderance based on length size class in Lake Habitat

The food composition of A. testudineus is quite varied, comprise animals form (insects, fish, and crustaceans), litter and plants (pieces of aquatic plants) and plankton, with the largest composition of food in animals form. [29] also found a similar result in Lake ArangArang Jambi, in which worms, fish, and detritus were dominantly found in A. testudineus stomach.

GMS analyses showed few A. testudineus was in level V, especially in lake site, where no specimen had enough maturity in level $\mathrm{V}$, but we will not discuss it in this study. In general, the composition of food types of A. testudineus based on the level of gonadal maturity can be categorized as food in the form of animals and plants. The tendency of animal composition is more dominant and increases with increasing size class (Figure 3 and Figure 4) and Gonad Maturity Stage (GMS) see table 2, whereas the composition of plants is relatively decreased. The results are in accordance with the opinion of [14], which states that changes in patterns of food habits are determined by the spread of organisms as fish food, food availability, choice factors of the fish itself, fish size and environmental physical factors.

Table. 2. Index of Preponderance based on the GMS of A. testudineus in Semayang Lake

\begin{tabular}{|c|c|c|c|c|c|c|c|c|c|c|}
\hline \multirow{2}{*}{ Sex } & \multirow{2}{*}{$\mathrm{N}$} & \multirow{2}{*}{ GMS } & \multicolumn{8}{|c|}{ Index of Preponderance (\%) } \\
\hline & & & Fish & Invertebrata & Debris & Plants & Plankton & Worm & ND & Snail \\
\hline \multicolumn{11}{|c|}{ Swamp Habitats } \\
\hline \multirow[t]{5}{*}{ Male } & 70 & I & 26.52 & 27.35 & 8.72 & 32.36 & 2.54 & 0.33 & 1.38 & 0.79 \\
\hline & 50 & II & 23.15 & 21.68 & 17.40 & 32.79 & 3.66 & & 1.32 & \\
\hline & 23 & III & 28.58 & 34.36 & 7.18 & 26.10 & 2.87 & 0.22 & 0.70 & \\
\hline & 22 & IV & 31.09 & 54.55 & 3.41 & 7.27 & 3.27 & & 0.41 & \\
\hline & 2 & V & & 42.50 & 22.50 & 27.50 & 6.50 & & 1.00 & \\
\hline \multirow[t]{5}{*}{ Female } & 50 & I & 30.17 & 22.81 & 10.43 & 31.04 & 2.89 & 0.52 & 0.62 & 1.51 \\
\hline & 42 & II & 38.13 & 21.97 & 13.68 & 23.15 & 2.45 & 0.12 & 0.50 & \\
\hline & 28 & III & 20.19 & 55.74 & 8.70 & 11.37 & 2.89 & & 1.11 & \\
\hline & 42 & IV & 18.95 & 67.44 & 3.54 & 5.32 & 4.37 & & 0.39 & \\
\hline & 3 & $\mathrm{~V}$ & 28.33 & 38.33 & 28.33 & 3.33 & 1.67 & & & \\
\hline \multicolumn{11}{|c|}{ Lake Habitats } \\
\hline \multirow[t]{4}{*}{ Male } & 57 & I & 26.98 & 28.67 & 11.88 & 27.03 & 2.40 & 1.72 & 1.32 & \\
\hline & 34 & II & 24.99 & 24.08 & 20.09 & 25.78 & 2.79 & 0.38 & 1.91 & \\
\hline & 21 & III & 18.57 & 51.86 & 11.76 & 12.48 & 3.95 & & 1.38 & \\
\hline & 13 & IV & 11.54 & 61.00 & 13.23 & 8.85 & 4.38 & 0.38 & 0.62 & \\
\hline
\end{tabular}




\begin{tabular}{ccccccccccc}
\hline \multirow{2}{*}{ Sex } & \multirow{2}{*}{ N } & \multirow{2}{*}{ GMS } & \multicolumn{7}{c}{ Index of Preponderance (\%) } \\
\cline { 4 - 9 } & & & Fish & Invertebrata & Debris & Plants & Plankton & Worm & ND & Snail \\
\hline Female & 31 & I & 27.40 & 24.33 & 11.13 & 29.47 & 2.77 & 0.30 & 1.10 & 3.50 \\
& 22 & II & 34.77 & 24.27 & 8.09 & 27.64 & 2.91 & 0.55 & 1.77 & \\
& 14 & III & 18.36 & 53.79 & 5.29 & 19.86 & 2.36 & 0.36 \\
& 34 & IV & 16.15 & 72.94 & 3.29 & 2.76 & 4.32 & 0.53 \\
\hline
\end{tabular}

Source: Primary Data, 2017-2018

Specifically, there are differences in the food composition of A. testudineus, but in terms of the kinds of food in the form of animals and plants, this condition might relate to different habitats. Furthermore, [14] stated that location and habitat for one species of fish might affect their food composition.

Generally, small-sized planktons are the initial food that is consumed by all types of fish in their starting life phase. As the fish grow, the need for food is adjusted to the requirements related to ontogenetic processes, the development of gonads, behavior before spawning, and foraging activities [14, 30, 31].

The composition and food types of A. testudineus in each habitat has similar pattern with the level of their gonadal development. The type of food in the form of animals (insects, fish, and crustaceans) always seemed to increase in line with the increase in gonadal development. This was thought to be related to the needs of nutrients, such as fatty and proteins, contained in the body of invertebrates and fishes for the development of gonads [32].

Food differences in the young and adult fish are affected by fish physiological conditions. As fish matured, the need for fats increased in order to stimulate the steroid hormones which plays a role in the process of gonadal maturation. To meet these needs, fish consume animals (fish, insects and crustaceans) which contains fats. [20] stated that when the fish is about to spawn, it will change its feeding composition, and then it will return to normal after spawning. Previous research $[33,34]$ added that there was a tendency to increase invertebrate food types with the development of Gonad maturity index (GMI) in Chromis pelloura and Eutropiichthys vacha fish.

\subsection{Trophic Level}

Empirically, it is known that A. testudineus is an omnivore (based on digestive macroanatomic studies and index of preponderance analysis). Based on Table 3, it can be seen that the trophic levels of male and female fish that were collected in swamp habitats are always above 2 values, with a range of trophic level values for male fish from 2.15 - 2.98 and female fish from $2.14-2.70$. Whereas for A. testudineus collected in lake habitat it has a relatively similar pattern, namely in male fish ranging from $2.233-2.420$, and in female fish ranging from 2.16 - 2.75 (Table 3).

Table 3. Trophic Level of A. testudineus in Semayang Lake

\begin{tabular}{|c|c|c|c|c|c|c|c|c|c|c|}
\hline \multirow{2}{*}{ Habitats } & \multirow{2}{*}{ Sex } & \multicolumn{9}{|c|}{ Length Class } \\
\hline & & 1 & 2 & 3 & 4 & 5 & 6 & 7 & 8 & 9 \\
\hline \multirow[t]{2}{*}{ Swamps } & Male & 2.28 & 2.26 & 2.29 & 2.38 & 2.39 & 2.15 & 2.93 & & \\
\hline & Female & 2.22 & 2.35 & 2.29 & 2.34 & 2.56 & 2.14 & 2.68 & & 2.70 \\
\hline \multirow[t]{2}{*}{ Lake } & Male & 2.26 & 2.29 & 2.30 & 2.23 & 2.42 & & & & \\
\hline & Female & 2.26 & 2.34 & 2.34 & 2.30 & 2.29 & 2.16 & 2.50 & & 2.75 \\
\hline
\end{tabular}

Source:Primary Data, 2017-2018

Information: 1: 95-114, 2: 115-124, 3: 125-134, 4: 135-144, 5: 145-154, 6: 155-164, 7: 165-174, 8: 175-184 and 9: 185-194. 
Results in table 3 showed that there is a tendency for an increase in trophic level values based on class size, meaning that the higher class sizes of omnivorous more inclined to carnivorous diet, especially in class size 165 - $194 \mathrm{~mm}$, while in class size $95-164 \mathrm{~mm}$ in the category of omnivores more inclined to herbivorous diet.

Trophic level status of $A$. testudineus with the category of omnivorous species more inclined to carnivorous diet, when associated with relatively small population numbers (Table 3), provides an understanding that the ecology of A. testudineus resources on Lake Semayang based on ecological pyramids is considered safe, with a degree of resource control to keep feed balance. According to a previous study [35] if the opposite occurs, it needs to be wary of the possibility of ecological imbalance. If the proportion of carnivorous fish gets too high, it will cause an imbalance in the ratio of prey and predators in food webs $[16,35$, 36]. The fish community trophic level approach can be used to evaluate the health and condition of the ecosystem, which is an essential initial link to be considered for maintaining the sustainability of fish resources $[15,37,38]$.

\section{Conclusion}

Index of Stomach Content (ISC) in the swamp habitat ranged from $4.32-39.59 \%$ with an average of $19.35 \%$, while in lake habitat ranged from $3.68-38.46 \%$ with an average of $16.03 \%$. From the results of feeding composition of A. testudineus, it can be inferred that the type of food in the form of animals is the main food (> 25\%), while the supplementary food is in the form of plants $(5-25 \%)$ and supplementary food in the form of plankton $(<5 \%)$. The composition of $A$. testudieus diets in the form of animals increases with increasing gonadal maturity. A. testudineus is categorized as an omnivorous type of fish that is more inclined to carnivorous diet as the length of the fish increases.

The authors would like to thank the Ministry of Research, Technology and Higher Education of Indonesia that have provided research grants, Dr. Jailani as manager of the laboratory of Aquatic Ecobiology Faculty of Fisheries and Marine Sciences, Mulawarman University which has provided facilities in supporting the present research. We also thank our student Syahidul Akbar, Muhammad Reva, Berlian Noor and Veni for the technical support given during the study.

\section{References}

1. M. Fakhrudin, C. Tjandra and R. Iwan. Kajian garis sempadan danau semayangSemayang untuk antisipasi penerapan PP no. 38 tahun 2011 tentang sungai. Prosiding Seminar Nasional Limnologi VI (2012).

2. M. Mustakim, S. Anggoro, F. Purwanti, Haeruddin. Length-weight relationships and condition factor of Anabas testudineus in the Semayang Lake, East Kalimantan, Indonesia. AACL Bioflux 12(1):327-337 (2019)

3. N. Romanowski. Living Water: Ecology of Animal in Swamps, Rivers, Lakes and Dams: Rebirth Of Lake (Chapter 9). CSIRO PUBLISHING 150 Oxford Street (PO Box 1139) Collingwood VIC 3066, Australia, 292. (2013)

4. J. Pokorný and S. Björk. Wetlands: Ecology, Conservation, and Management: Restoration of lake, Streams, Floodplains and Bogs in Europa (Principles and Case Studies). Development of Aquatic Macrphytes in Shallow Lakes and Ponds. Springer Dordrecht Heidelberg London New York, 37 - 43 P. (2010)

5. R.T. Corlett, \& R. B. Primack. Tropical Rain Forests: An Ecological and Biogeographical Comparison (2nd ed.). Hoboken, NJ: Wiley-Blackwell, 335 pp. (2011) 
6. O.R. Lopez, \& T. A. Kursar. Interannual Variation in Rainfall, Drought Stress and Seedling Mortality May Mediate Monodominance in Tropical Flooded Forests. Ocologia, 154: 35-43. (2007)

7. O.W. Archibold. Ecology of World Vegetation. Springer Science+Business Media Dordrecht. Department of GeographyUniversity of Saskatchewan Saskatoon, Canada, 510 PP. (1995)

8. G. Wahyudewantoro. Pengelolaan Perikanan di Danau Semayang. Kalimantan Timur. Fauna Indonesia. 13 (1): 45-50. (2014)

9. M. Mustakim, S. Anggoro, F. Purwanti, Haeruddin. Population dynamics of the climbing perch Anabas testudineus in the Semayang Lake, East Kalimantan Province, Indonesia. AACL Bioflux 11(4):1038-1046. (2018)

10. M.A. Alam, A. Noor, M.M. R. Khan, and Rahman, L. Growth performance and morphological variations of local and Thai climbing perch (Anabas testudineus, Bloch). Bangladesh]. Fish. Res., 11(2): 163-171 (2007)

11. Zalina, C.R. Saad, A.A. Rahim, A Christianus., S.A. Harmin. Breeding performance and the effect of stocking density on the growth and survival of climbing perch, Anabas testudineus. Journal of Fisheries and Aquatic Science. 6 (7): 834-839. (2011)

12. Helmizuryani and B. Muslimin. Growth Performance of Mono Sex and Mixed Sex Climbing Perch (Anabas testudineus). Omni-Akuatika 12 (2): 99 - 103. (2016)

13. Y. Ernawati, M.M. Kamal, and N.A.Y.Pellokila. Biologi Reproduksi Ikan Betok (Anabas testudineus Bloch, 1792) Di Rawa Banjiran Sungai Mahakam, Kalimantan Timur. Jurnal Ikhtiologi Indonesia 9(2): 113-127 (2009)

14. M.I. Effendie. Biologi Perikanan. Yayasan Pustaka Nusantara. Yogyakarta (2002)

15. K.I. Stergiou, \& V.S. Karpouzi. Feeding habits and trophic levels of Mediterranean fish. Fish Biology and Fisheries 11: 217-254. (2002)

16. E. Chassot, D. Gascuel, and A. Colomb. Impact of trophic interactions on production functions and on the ecosystem response to fishing: a simulation approach. Aquat. Living Resour. 18: 1-13. (2005)

17. Z. Zuliani, Z. A. Muchlisin, N. Nurfadillah. Jurnal Ilmiah Mahasiswa Kelautan and Perikanan Unsyiah 1(1): 12-24. (2016)

18. E.J. Hyslop. Stomach contents analysis- a review of methods and their application. Journal Fish Biology, 17(41): 411-429 (1980)

19. H. Bruce. An Alternative to the Fullness Index. Division of Wildlife and Fisheries Biolgy, University of California, Davis, CA 95616.USA (1986)

20. M.I. Effendie. Biologi Perikanan. Yayasan Dewi Sri. Bogor (1997)

21. A.Rachman, T. Herawati., and H. Hamdani. Kebiasaan Makanan dan Luas Relung Ikan Di Cilalawi Waduk Jatiluhur Kabupaten Purwakarta Provinsi Jawa Barat. Jurnal Perikanan dan Kelautan,3(2):79-87. (2012)

22. A.J. Mearns, D.R. Young, R.J. Olson \& H.A. Schafer. Trophic Structure and the CesiumPotassium Ratio in Pelagic Ecosystems. CalCOFI Rep., XXII: 99-110. (1981)

23. M.F. Rahardjo D.S. Sjafei, R. Affandi, Sulistiono, J. Hutabarat. Iktiology. Bandung: CV Lubuk Agung. 398 hal. (2011)

24. A.I. Burhanuddin. Ikhtiologi, Ikan dan Segala Aspek Kehidupannya. Deepublish, Yogyakarta, $421 \mathrm{hlm}$. (2014)

25. R. Affandi, D.S. Syafei, M.F Rahardjo, Sulistiono. Fisiologi Ikan Pencernaan dan Penyerapan Makanan. Pusat Antar Universitas Ilmu Hayat. IPB. 160 hal. (1992)

26. M. Jobling. Environmental Biology of Fishes. Fisheries Science. University of Tromansa. Norway. Chapman \& Hall. 455 p. (1995)

27. P.B. Moyle. and Jr. J. Cech. Fishes: An Introduction to Ichtyology. $5^{\text {th }}$ edition. New Jersey: Prentice-Hall. Inc. (2004) 
28. Elrifadah. Analisis Feeding Periodicity Ikan Betok (Anabas testudineus Bloch) Yang Tertangkap Di Perairan Rawa Malintang Baru Kecamatan Gambut Kabupaten Banjar Provinsi Kalimantan Selatan. Enviro Scienteae 11: 131-135. (2015)

29. Samuel, S. Adjie, Z. Nasution. Aspek Lingkungan dan Biologi Ikan di Danau ArangArang Prop. Jambi. Jurnal Penelitian Perikanan Indonesia, 8 (1): 1-13. (2002)

30. R.L. Welcomme. Fisheries ecology of flood plain rivers. Longman. New York. USA. pp 50-53. (1979)

31. S. Dadzie, F. Abu-seedo, E. Al-Qattan. The food and feeding habits of the silver pomfret, Pampus argenteus (Euphrasen), in Kuwait waters. Journal Applied Ichthyology, 16: 6167. (2000)

32. T. Watanabe, T. Fujimura, M.J Lee, K. Fukusho, S. Satoh, \& T. Takeuchi. Effect of polar an non polar lipids from krill on quality of eggs of red seabream Pagus major. Nippon Suisan Gakkaishi 57(4): 695-698. (1991)

33. M. AL-Zibdah and N. Kan'an. Aspects of Growth, Reproduction, and Feeding Habit of Three Pomacentrid Fish From Gulf of Aqaba, Jordan. Jordan Journal of Biological Sciences., 2(3): 119-128 (2009)

34. A.N. Soomro,, W.A. Baloch. S.I.H. Jafri, G.H. Burdi and B. Fulanda. Reproduction and feeding habits of the River Catfish Eutropiichthys vacha (Hamilton, 1822) (Siluriformes, Schilbidae) in an impacted habitat: Kotri hydrodam, River Indus, Pakistan. Our Nature 10: 269-280. (2012)

35. R. Fugi, K.D.G. Luz-Agostinho \& A.A. Agostinho. Trophic interaction between an introduced (peacock bass) and a native (dogfish) piscivorous fish in a Neotropical impounded river. Hydrobiologia, 607: 143-150. (2008)

36. J.F. Caddy, \& G. D. Sharp. An Ecological Framework for Marine Fishery Investigations. FAO Fish. Tech. Pap. 283. 152 pp. (1986)

37. Sriati, S. Sukimin, V.P. Siregar, S. Woutuyzen, \& A. Sunudin. Trofik level komunitas ikan di ekosistem terumbu karang Kepulauan Seribu. Prosiding Seminar Nasional Tahunan VI. Hasil Penelitian Perikanan dan Kelautan: BI-13, 1 - 7 pp. (2009)

38. A.A. Sentosa, and H. Satria. Kebiasaan Makan Beberapa Jenis Ikan yang Tertangkap di Rawa Kaiza Sungai Kumbe Kabupaten Merauke, Papua. Limnotek 22(1): 32-41. (2015) 